\title{
THE COMPARISON STUDY ON TWO-TYPES OF STUDENTS` PERSONALITY: SANGUINE AND PHLEGMATIC TOWARD THEIR ENGLISH SPEAKING ABILITY
}

\author{
Lisa Rakhmanina ${ }^{1}$, Feny Martina ${ }^{2}$, Nevan Jayadi ${ }^{3}$ \\ ${ }^{1}$ University of Prof. Dr. Hazairin, S.H., Bengkulu \\ ${ }^{2}$ Institut Agama Islam Negeri Bengkulu \\ ${ }^{3}$ University of Prof. Dr. Hazairin, S.H., Bengkulu \\ ${ }^{1}$ lisarakhmanina83@gmail.com, ${ }^{2}$ feny@iainbengkulu.ac.id, ${ }^{3}$ jayadinevan52@gmail.com
}

\begin{abstract}
The study is an attempt to find out the difference between Sanguine and Phlegmatic personality toward their speaking ability. The design in this study was comparative analysis design. The samples of this study were 44 students from Faculty of Law. Personality test was carried out to decide whether the students were categorized to the group of Sanguine or Phlegmatic. Furthermore, the researcher used personal description for monologue speaking technique for testing the students speaking skills. The data were analyzed by using t-test formula to investigate whether there was significant difference result between the Sanguine and the Phlegmatic students in their speaking skill. From the result of the study, it could be concluded that there was no significant different result between the Sanguine and the Phlegmatic students toward their speaking skill. It means, there were not any better students in speaking between both Sanguine and Phlegmatic students. Those two personalities, the Sanguine and the Phlegmatic students could perform better English speaking skill through their own personal way.
\end{abstract}

Keywords: Comparison Study, Sanguine, Phlegmatic, Speaking Ability

\section{INTRODUCTION}

Communication happens in anywhere and at anytime. Hovland, Janis, and Kelly (1953) in Rakhmat (2007: 3) explain communication as the process by which an individual (the communicator) transmits stimuli (usually verbal) to modify the behavior of other individuals (the audience). Most of the communication process uses language. When a language is used, actually, the communication process of sharing ideas and thoughts happens. Language is about expressing ideas, values and attitudes of its member.

To run a smooth and communicative communication, speaking skill of someone is playing important role. It is also the most used skill among other three skills. Meanwhile, for many of people, speaking is as natural as we waking up each day and talk; it is unconscious process which people rarely notice they are actually doing it. It is obvious that having good results in learning English, an individual might need to speak spontaneously or automatically.

A person with good speaking ability, he or she might have good personal confidence. Through speaking, an individual could conduct a task quicker, faster, more influencing and motivating. It is also about having direct and quick decision making, or self action without waiting. Courage is the first thing an individual should have before mastering speaking, that is about the courage to share and debate personal ideas, thoughts, opinions, and values. 
Nunan (1989: p.26) states that speaking is to use spoken language consisting of short, incomplete or separate speech in pronunciation. The pronunciation is closely related to the reciprocal relationship that is made between a speaker and the listener. The conversation between two or more individuals that securely bond them is the case of reciprocal relationship. According to Tarigan (1992), speaking is a form of human behavior that utilizes very intense physical, psychological, neurological, semantic and linguistic factors.

A secure bond is needed through speaking process. It is psychologically affect individuals speaking achievement. For language learners, feeling secure is important and significantly influences the result process of learning a foreign language. Most of the students were born in different characters and personality. Negative impacts that usually happen in classroom contribute significant influence to the students. Not all the students could accept those negative impacts with a brave heart. Some might react well by turning the negative impacts upside down. Meanwhile, some might feel hurt and be on the spot. The different reaction shows that students' personality influence the students` way of learning a language. From most of studies, personality is a learner variable that has been associated with success in language learning and use (Nodoushan, 2011).

There are claims that a learner's personality is a determinant of his or her language use or success (Pennebaker \& King, 1999) as cited in Nodoushan (2011). According to Leibnitz as cited in Lundin $(1969$, p.3), personality referred to 'a substance gifted with understanding'. It took into consideration, when a problem, an experience, or a conflict is given to several students, they might show various reaction. Some of them might feel happy, some might show stern reaction, and others might give bad reaction. Reaction is something unforced and not under control.

There is an idea that personality is what real person is, it is the truth of he or she is. When psychologists use the term "personality," they are referring to something more than the role people play (Feist \& Feist, 2008, p.9). Furthermore, personality is a pattern of relatively permanent traits and unique characteristics that give both consistency and individuality to a person's behavior (Feist \& Feist, 2008, p.10). Understanding a person's personality is a hard task. Personality deals with a wide range of human behavior, includes mental, emotional, social and physical (Ewen, 2003). Those behaviors are the manifestation of their action that invites reaction. This reaction is what is understood as 'temperament'.

The word temperament comes from 'Temperamentum', a Latin word which means proper mixing, and the idea behind it was that if the human body fluids were reduced in their intensity by balancing the humors with each other, then healing would occur (Media Spotlight, 1994) as cited in Okal, Ambuyo, Amukowa (2012). They (2012, p.56) also stated that temperaments are inborn traits. Hippocrates introduced Four Temperaments, they are Sanguine, Choleric, Melancholic, Phlegmatic.

Sanguine is cheerful, friendly, talkative, lively, restless, self-centered and undependable; Phlegmatic is calm, dependable, efficient, easy-going, passive, stubborn and lazy; Choleric is optimistic, active, confident, strong-willed, quick to anger, aggressive and inconsiderate and Melancholic is melancholic/sad, sensitive, analytical, perfectionist, unsociable, moody and rigid ((Martin and Bobgan, 1992) as cited in Okal, Ambuyo, Amukowa (2012)). These temperaments give significant impact on the lives of the students. Nyongesa (2004) divided these temperaments into two big categories: Sanguine and Phlegmatic. Moreover, the Sanguine category refers to sanguine (as super Sanguine) and choleric (lower level of Sanguine), while, 
the Phlegmatic category refers to phlegmatic (as super Phlegmatic) and melancholic (low level Phlegmatic).

In classroom, students are having various characters of temperaments. These build strong influence on how they could manage their learning process. Differences on temperaments also create larger gap in learning achievement, including speaking achievement. Speaking forces students not to feel shy or unconfident. It is undeniable, that a willingness to be active, open minded, and confident is important in building up reciprocal relationship between one person and the other. From the four temperaments, the Sanguine category seems suitable in becoming active in speaking activity or language learning. The outgoing personality and extroversion show significant aspect in language learning (Nodoushan, 2011). The traits that lie in Sanguine and Choleric are suited enough. Meanwhile, the Phlegmatic group (Phlegmatic and Melancholic) seems show vice versa.

Based on the explanation above, this writer of this study chooses Sanguine (Super Sanguine) and Phlegmatic (Super Phlegmatic) as her main of study. These two types of temperaments are mostly found in the classrooms. The writer analyzes their differences and similarities regarding their characters and their English speaking achievement. The writer of the study plans to conduct a comparative study entitled ' The Comparison Study on Two-types of Students` Personality: Sanguine and Phlegmatic toward their English Speaking Skill.

The importance of this study is to study the personality of the students and how do the students react toward the process of language learning. Furthermore, in this study, the primary data needed was the group of personality based on the students` personality test result. The two main personality being concerned in this study is Sanguine and Phlegmatic. Furthermore, students in Sanguine and Phlegmatic groups were being asked to describe themselves in English and their speaking ability were being evaluated. At the end, these two data were analyzed and compared in order to find out which personality was performing better related to speaking skill. The output of this study was data of comparison of personality of Sanguine and Phlegmatic that could be functioned as the basis data for teaching. Moreover, teachers can teach speaking skill effectively and efficiently based on their personality.

\section{The Importance of Speaking}

Speaking is about delivering messages from one speaker to other listener orally. Speaking is an interactive process of constructing meaning that involves producing and receiving and processing information (Brown, 1994). Speaking is called an interactive process as it needs students` ability to manage their thoughts, encode the ideas and translate or transfer the code into good response. According to Brown (2001), in all communication or conversation two people are exchanging information or they have a communication or conversation need. Speaking could also be called as multitasking skill. It is the final representation from the final process of learning a language. When a student could give proper response to a conversation by using the language being learnt, speaking process reaches the need.

Speaking is important as it could support the students as language learner to communicate in target language for many of individuals` need in the future. It could only be seen only when the process of conversation among individuals happen. Speaking is also about the ability of 
individual to express more about him, as it mostly happens during the personal presentation in interview process or in introducing themselves to other people.

Rakhmanina and Yuneva (2018) stated that speaking is also called as multitasking skill which requires language learners to learn: grammar, pronunciation, and vocabulary. Those aspects sometimes are neglected by the language learners. The followings are the basic speaking skills that an individual must possess (Setiowati, 2015), including many aspects as follows:

1. Speak different sounds clearly so that the listener can tell the difference.

2. Use pressure and tone and clear and accurate intonation so that the listener can understand what the speaker is saying.

3. Using word forms, word order, and appropriate word choice.

4. Use the appropriate register or variety of languages for communications situations, including in accordance with the relationship between the speaker and the listener.

5. Seek to make the main sentences clear to the listener.

6. Seek to propose additional ideas or information to explain the main ideas.

7. Strive for discourse to harmonize in harmony so that listeners easy to follow the conversation.

Brown (2001) says that much of our language teaching is devoted to instruction in mastering English conversation. He (2001) classifies types of oral languages into monologue and dialogue form. Brown (2001) also provides type of classroom speaking performance, they are imitative, intensive, responsive, transactional, interpersonal, and extensive.

\section{The Concept of Personality}

Understanding personality means the ability to understand someone`s characteristics. When somebody said, 'That man is so talkative' or 'She is very shy', he or she is actually trying to express someone characters. The more those character express on any individuals, the more the characters are getting more transparent. That is personality.

Individuals are specific and unique; they are different from one another. It also relates to their personality. Personality refers to stable behavior of individuals. It may be observable or unobservable and conscious and unconscious. Understanding personality is challenging task. Let us consider the sentence, 'She is shy'. That girl might be shy in any occasion, when she is with her friends, teachers and others. Moreover, she could be someone who is outgoing if she is with her family. It shows totally different. Personality is not static; it is more dynamic. Personality is the dynamic organization within the individual of those psychophysical systems that determine his unique adjustments to his environment (Hall \& Lindzey, 1987).

Alport (1961) stated that personality is the dynamic process within individuals. Larsen and Buss (2009) defines personality as the set of psychological traits and mechanisms within the individual that are organized and relatively enduring and that influence his or her interactions with, and adaptations to, the intra-psychic, physical, and social environments. Well-managed traits make students getting better as they might experience good process of adaptation and interaction. When they are experiencing better traits, they are ready for school and being educated. 
There are numbers of personality theories. Personality of individuals are determined by nature (heredity) or nurture (environment or learning). Personality that comes from function of nature (or heredity) is called temperament. Temperament is aspect of our personalities that is genetically based, inborn, and from birth (Kasschau, 1985). Temperament is biological-based. Eysenck (1947) argues that personality is also temperament. There are four temperaments introduced by Hippocrates, they are: Sanguine, Choleric, Phlegmatic and Melancholic. Furthermore, Eysenck classifies the four temperaments according to two scalable dimensions whereas other models define personality according to one of the four temperaments (Boeree, 1997) as seen in Figure 1. In his classification, Eysenck classified the four personality into two big groups: Sanguine and Phlegmatic. Nyongesa (2004) also divided these temperaments into two big categories: Sanguine and Phlegmatic. Moreover, the Sanguine category refers to sanguine (as super Sanguine) and choleric (lower level of Sanguine), while, the Phlegmatic category refers to phlegmatic (as super Phlegmatic) and melancholic (low level Phlegmatic).

STABLE

\begin{tabular}{|c|c|c|c|c|c|}
\hline & \multicolumn{2}{|c|}{ SANGUINE } & \multicolumn{2}{|c|}{ PHLEGMATIC } & \\
\hline & Leadership & Responsive & Calm & Peaceful & \\
\hline & Carefree & Talkative & Even-tempered & Thoughtful & \\
\hline \multirow{7}{*}{$\begin{array}{c}\text { SANGUI } \\
\text { NE }\end{array}$} & Lively & Outgoing & Reliable & Careful & \multirow{7}{*}{$\begin{array}{l}\text { PHLEG } \\
\text { MATIC }\end{array}$} \\
\hline & Easygoing & Sociable & Controlled & Passive & \\
\hline & \multicolumn{2}{|c|}{ CHOLERIC } & \multicolumn{2}{|c|}{ MELANCHOLIC } & \\
\hline & Active & Excitable & Quiet & Sober & \\
\hline & Optimistic & Aggressive & Unsociable & Rigid & \\
\hline & Impulsive & Restless & Reserved & Anxious & \\
\hline & Changeable & Touchy & Pessimistic & Moody & \\
\hline
\end{tabular}

UNSTABLE

Figure 1. Eysenck`s Personality Type

Nodoushan (2011) stated that there are many studies indicate that personality could be correlated with language learning and use. Zhang (2008) stated that Sanguine learn a second language more easily because they are more risk-taking; they are not afraid of embarrassing themselves by speaking incorrectly, or by not being able to speak at all, so they do not miss the opportunities that can help their learning.

\section{Sanguine}

Sanguine is super Sanguine. Sanguine is cheerful, friendly, talkative, lively, restless, selfcentered, sociable and undependable. Sanguine is usually a pleasure-seeking and charismatic. The heart of sanguine is very soft and they act before they think. The Sanguine side of sanguine is dominant. Sanguine is a high confident type of persons so that he or she lives in optimistic. The optimistic live the Sanguine experience also created them to be pleasure seekers. They do not feel worry; they enjoy the outdoor activity.

As explained above, Sanguine has strengths. The strengths of Sanguine express the real Sanguine, which are: Sanguine and optimist. Sanguines have great response toward the lives 
around them. Most Sanguines love travelling, adventuring and exploring new things. In social lives, Sanguines are nice helpers. They tend

In classroom, Sanguines tend to be talkative, cheerful, calm and enthusiast. They could become example as they can influence good atmosphere of learning to other students. They truly could become the star of the class. Sanguine students are fast learners. They could easily understand the materials.

Sanguines are also with weaknesses. They tend to have difficulties in memorizing the learning materials. They need to reread the material several times in order to gain comprehension. They are forgetful since they sometimes may find things interested them and directly forget what is in front of them. They tend to be indiscipline, messy, and easily-tempered. Sanguines dislikes being alone, they look as having strong characters but the fact is they a little bit weak in facing the truth. As students, Sanguines mostly want to be the best and perfectionist.

\section{Phlegmatic}

Phlegmatic is categorized in Phlegmatic group or having super Phlegmatic category. Basically. Phlegmatic is a typical person who likes to stay away from problems. Phlegmatic tends to calm, very hard to get angry, and has balanced live. The phlegmatic is peaceful person, born-follower, likes harmony and rest, loves to relax, wants to calm people down, easy to get along with everyone, needs peace and sense of worth, has little self-motivation, gets depressed over conflict, controls by procrastination (Litteaur, 2012).

Phlegmatic tends to love peace and harmony. That is why phlegmatic usually love to become mediator or diplomat since phlegmatic is able to mediate people in conflict. That is the strength of phlegmatic. As mention earlier, phlegmatic is regarded as humorous. Moreover, phlegmatic has traits of being friendly, shy, good listener, pleasant and has sense of humor. Most phlegmatic individuals have consisted lives.

\section{METHOD}

The study was conducted in University of Dr. Hazairin, SH at the Faculty of Law. The study held on April 2018. The writer of the study had the students from Law of Science Major, Faculty of Law, University of Prof. Hazairin, SH as the participants of the study. The writer conducted the speaking test to the second semester students which consisted of 75 participants. Based on personality test, the results were as follows: There were 17 students belonged to Choleric, 23 students were Sanguine, 10 sudents were Melancholic, and 25 students were Phlegmatic. Those who belong to Sanguine and Phlegmatic Group of Personality were faced the speaking Test. This study used 22 students for Sanguine personality and 22 students for Phlegmatic.

The method of the study was quantitative method by applying comparative study using a largescale survey. The survey was questionnaire of personality test and delivered to students in order to find out students` types of personality. Furthermore, the students were also having speaking test to find out their speaking achievement.

The data was analyzed by using comparative analysis. Comparative study was suitable for a researcher who plans on conducting a research that has two or more independent variables. This method of research was conducted to find out the differences between variable being tested. If the differences had been found out, the further step conducted was about finding out whether 
the difference was by chance or truly significant. Thus, the data obtained would be more objective.

The procedure of the research process in this study was started on delivering personality test to the students. This personality test was delivered in order to find out the personality differences of the students. The personalities that would be taken into research were Sanguine and Phlegmatic. Furthermore, the students that had already been in the groups were having speaking test. It was for finding out their speaking achievement. After that, the students from the two personalities were compared in order to find out which personality could perform speaking better, the Sanguine or the Phlegmatic.

The instruments for collecting the data in this study were personality test and speaking test. Personality test refers to a test for judging whether a student belong to certain type of personality. The personality test had 40 lines of words consists of four traits or characters in each line that was divided into two: 20 for the strengths and 20 for the weaknesses. Students were asked to cross one among four of the traits that truly describes him or her. If the student feels unsure, she or he could ask the friends for clarifying and later ask himself or herself again for sure. The students personality was being judged by examining the questionnaire and grouping the students into four group: Sanguine, Choleric, Phlegmatic and Melancholic. Moreover, the students in Sanguine and Phlegmatic Groups are only being the participants of the study. The personality test was ready made and standardized since it belongs to Florence Littauer. The test consists of 40 lines, where each line has four traits that reflected the four temperament, Sanguine, Choleric, Phlegmatic and Melancholic.

The speaking test was about description of oneself. The students were asked to describe themselves and record them. Furthermore, two raters scored their speaking performances based on the speaking rubric. It is for one reason that the data gained was fair.

The technique for analyzing the data was done by analyzing the personality of the students. The students who have taken the test were grouped into four personality group: Sanguine, Choleric, Phlegmatic and Melancholic. Moreover, there were only Sanguine and Phlegmatic that took into consideration as the participant of the study. After having the Sanguine and Phlegmatic students, the students were asked to perform speaking test. They had to describe about themselves and the rater recorded them. The result of the recording process was scored by two independent raters to be judged fairly.

Furthermore, the calculation of speaking test was conducted by using score from speaking rubric. The result of this scoring carried out into two part of tables, one part for Sanguine Groups`result, and other part for Phlegmatic Group.

\section{RESULTS AND DISCUSSION}

\section{Results}

\section{The English Speaking Skill of the Sanguine and the Phlegmatic Students}

The writer did the assessment of English speaking skill of students from five points as follows: fluency, grammar, accent, diction, and comprehension. The researcher used English speaking test. Both the Sanguine student and the Phlegmatic described themselves as a monologue description in English speaking test. The processes were video-taped and recorded. The results 
showed in the following table 1. Based on the data in Table 1, the Sanguine students get better English speaking score on the point of accent and fluency.

Table 1. The Average and Percentage Score of the Speaking Test of the Sanguine (Speaking Aspects)

\begin{tabular}{lccccc}
\hline & Fluency & Grammar & Accent & Diction & Comprehension \\
\hline Total & 110 & 84 & 93 & 110 & 90 \\
Average & 5.0 & 3.8 & 4.22 & 5.0 & 4.1 \\
Percentage & $22.5 \%$ & $17.24 \%$ & $19.1 \%$ & $22.59 \%$ & $18.48 \%$ \\
\hline
\end{tabular}

Table 2. The Average and Percentage Score of the Speaking Test of the Phlegmatic (Speaking Aspects)

\begin{tabular}{cccccc}
\hline & Fluency & Grammar & Accent & Diction & Comprehension \\
\hline Total & 92 & 110 & 87 & 89 & 107 \\
Average & 4.18 & 5.0 & 3.95 & 4.04 & 4.86 \\
Percentage & $18.96 \%$ & $22.68 \%$ & $17.93 \%$ & $18.35 \%$ & $22.06 \%$ \\
\hline
\end{tabular}

Based on the Speaking Tests tables above, the Sanguine students performed better in the aspects of fluency, accent, and diction than Phlegmatic students. In this test, the Sanguine students got $22.5 \%$ in fluency aspect while the Phlegmatic students got $18.96 \%$. In the aspect of diction, the Sanguine students' percentage is $22.59 \%$ while the Phlegmatic students' percentage is $18,35 \%$. Meanwhile, in terms of fluency, the Sanguine students scored in $22.5 \%$ while the Phlegmatic students scored in $18.96 \%$.

Moreover, the Phlegmatic students performed better in terms of grammar and comprehension than the Sanguine students. Those table shows that the percentage of the 22 Phlegmatic students in the aspect of grammar is $22,68 \%$ while the Sanguine students' percentage in the grammar aspect is $17.00 \%$. Meanwhile, in the aspect of comprehension, the Phlegmatic students gained $22,06 \%$ and the Sanguine students gained $18.48 \%$.

\section{Results in English Speaking Ability}

The Sanguine students are assumed to have a good ability and better ability in speaking. In this research, their score of speaking 88,54 in average. The Phlegmatic students are well-known as the stolid persons; they are estimated to be a person who has less ability in speaking than the Sanguine. However, the average of the Phlegmatic students is 88,18 . The data tells that the score of the Sanguine students in English speaking skill is a little bit higher than the Phlegmatic students. The Sanguine students in Law Faculty proved that the theory is true. Moreover, through times, they sometimes could be untrue. Lestari and Suhartono (2013) states "Extroverts can control classroom communicative activities with less fear of risk-taking comparing to their introvert peers; however, introverts are probably more conscientious and devoted to their task". 
Sanguine personality tends to love talking to other people, attract people with lovable sense of humor and expressive. They would often show incredible enthusiasm and high confidence.

Table 1. Number of Students Based Early Mathematical Ability

\begin{tabular}{ccc}
\hline PAM & Experiments & Control \\
\hline High & 11 & 12 \\
Medium & 53 & 44 \\
Low & 9 & 10 \\
\hline Total & 73 & 66 \\
\hline
\end{tabular}

\section{CONCLUSION}

There are three conclusions obtained. The first conclusion also related to the first formulation of the research that asked about the distribution of the type of personality in Faculty of Law students. Based on the data result in this study, the percentage showed 42,30\% for the Sanguine personality, and 57,70\% for the Phlegmatic. It could be concluded that Sanguine had a smaller number than Phlegmatic.

The second conclusion is about how is the English speaking skill of the Sanguine and the Phlegmatic students. Based on the data, the Sanguine students gained 88,54 in average while the Phlegmatic students get 88,18 in average. It showed that the Sanguine students got higher average of English speaking score than the Phlegmatic students. It explained that Sanguine and Phlegmatic students have the equal superiority in this study. The Sanguine students were better in the points of accent (19.1\%), diction (5.0\%), and fluency (22.5\%) than the Phlegmatic students who get the percentage of 17.93 for aspect of accent; $18.35 \%$ for diction; and $18.96 \%$ for fluency. However, the Phlegmatic students performed better in aspect of grammar that was $22.68 \%$ and comprehension for $22.06 \%$ than those of the Sanguine students who get the percentage of 22.5 for grammar and $18,48 \%$ for comprehension. These data showed that the Sanguine students was a little bit better in the aspect of accent, vocabulary and fluency while the Phlegmatic students were better in the aspect of grammar and comprehension.

The third conclusion asked about how the Sanguine students performed better than the Phlegmatic students in English speaking skill. The data showed that the average of the Sanguine students was higher from the Phlegmatic students. The causes were the Sanguine students were good in three aspects from the five aspects of speaking that were accent, diction and fluency; while the Phlegmatic students performed good in two aspects that were grammar and comprehension. It is related with the Sanguine students ' personality who were more active in speaking. The Sanguine students were easy to practice and remind the pronunciation or imitate the active speaker when they practice English in speaking in the class. Meanwhile, the Sanguine students did not pay attention to the structure of the sentence that make they gained the lower score in the aspect of grammar and less in the aspect of comprehension. However, the Phlegmatic students who were characterized as the stolid person prefer to observe than to practice.

The fourth conclusion asked about the significant difference result between the Sanguine and Phlegmatic students in their speaking ability. Based on the result of the study, the $t_{\text {table }}$ was 2.074 and $t_{\text {observation was }} 0.361$ for degree of freedom (44) at significance level of 0.05 (5\%). The T- 
observation was smaller than the t-table 0.05 levels of significance. It is shown that there was no significant difference between students in Sanguine Personality and those in Phlegmatic personality in terms of their English speaking ability. It means that both personality (Sanguine and Phlegmatic) performed equally in English speaking activity with their own personal way. Consequently, further study needs to be conducted with larger samples and linguistic point of view to enrich the scientific knowledge and to make the generalization of the case.

\section{ACKNOWLEDGMENTS}

We thank the family, parents, friends who have given us support both morally and materially, so that we can complete and publish our article.

\section{REFERENCES}

Amberg, J. S., \& Vause, D. J. (2009). American English: History, Structure, And Usage (Pp. 110). Cambridge, Ma: Cambridge University Press.

Arsjad, M. G., \& Mukti, U. S. (1988). Pembinaan Kemampuan Berbicara Bahasa Indonesia. Erlangga.

Brown, H.D. (1994). Teaching By Principles: An Interactive Approach To Language Pedagogy. Englewood Cliffs, $\mathrm{Nj}$ : Prentice Hall Regents.

Brown, H. D. (2001). Teaching By Principle An Interactive Approach To Language Pedagogy. San Francisco: Longman

Ewen, B.R. (2003). An Introduction To Theories Of Personality, Sixth Edition. New Jersey: Lawrence Erlbaum, Associates Publishers.

Eysenck, H. J. (1947). Dimensions Of Personality (Vol. 5). Transaction Publishers.

Feist, J., \& Feist, G.J. (2008). Theories Of Personality, Seventh Edition. New York: The Mcgraw-Hills Companies.

Hall, C.S., \& Linzey, G. (1987). Theories Of Personality. $3^{r d}$ Ed. Toronto: John Wiley \& Sons, Inc.

Kasschau, R. A., \& Maxwell, C. B. (1985). Psychology, Exploring Behavior: Teacher's Guide With Tests. Prentice-Hall.

Lestari, A., Sada, C., \& Suhartono, L. (2013). Analysis On The Relationship Of ExtrovertIntrovert Personality And Students' Speaking Performance (Doctoral Dissertation, Tanjungpura University).

Littauer, F. (2012). After Every Wedding Comes A Marriage. Harvest House Publishers.

Nunan, D. (1989). Designing Task For The Communicative Classroom. Cambridge: Cambridge University Press.

Okal, B. O., Ambuyo, B. A., \& Amukowa, D. N. (2012). The Functionality Of Four Temperaments And Communication Theories Towards The Realisation Of Peaceful General Elections In Kenya. Journal Of Sociological Research, 3(1), 55-66.

Rakhmanina, L., \& Yuneva, Y. (2018). The Application Of Instagram Activity To Improve Studentsmotivation In English Speaking. Edu-Ling: Journal Of English Education And Linguistics, 2(1), 49-59.

Rakhmat, J. (2007). Psikologi Komunikasi. Bandung: Pt Remaja Rosdakarya.

Larsen, R., \& Buss, D. M. (2009). Personality Psychology. Chennai: Mcgraw-Hill Publishing.

Salmani Nodoushan, M. A. (2011). Temperament As An Indicator Of Language Achievement. Online Submission, 5(4), 33-52.

Tarigan, D. (1992). Materi Pokok Pendidikan Bahasa Indonesia I Buku Ii. 4 Modul 1-6. 